\title{
THE WASTED YEARS
}

\section{In the first of three features on the legacy of the Bush administration, Declan Butler looks at the United States' failure to deal with the risks of nuclear proliferation.}

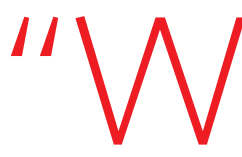

here do I start? One could
write a book," sighs Frank
von Hippel, a nuclear-
we a o ons expert at

Princeton University in New Jersey. He rattles off a litany of the ways in which he believes the administration of George W. Bush has harmed the cause of nuclear non-proliferation. The list includes the Iraq war, the administration's scuttling of the Nuclear Non-Proliferation Treaty (NPT), its opposition to the Comprehensive Test Ban Treaty, its pursuit of missile-defence schemes and a nuclear deal with India, and its foot-dragging on reductions in nuclear weapons. "The Bush administration did about as much damage to non-proliferation as one could imagine anybody doing," says von Hippel.

That gloomy assessment is largely shared by other experts. "For non-proliferation, the Bush administration has represented at best stagnation, and in many places retrogression," says Christopher Paine, a nuclear-weapons expert at the Natural Resources Defense Council in Washington DC. "All in all, not a good record." And for Daryl Kimball, executive director of the Washington-based Arms Control Association, the Bush administration has "left the world demonstrably less secure today than it was a decade ago with respect to nuclearweapons-related threats".

The international nuclear non-proliferation regime depends on an interconnected, fragile system of trust, confidence, and diplomatic and regulatory checks and balances built up over decades around the NPT, Kimball explains. Although cheats of the NPT regime, such as North Korea, have rightly attracted prominent concern, eight years of less-conspicuous non-proliferation deregulation under Bush has undermined the regime itself, say experts.

Indeed, some find the situation depressingly similar to the recent carnage in the financial markets. One such example is Joseph Cirincione, president of the Ploughshares Fund, a grantmaking facility in San Francisco, California, that supports projects to prevent the spread and use of nuclear weapons. Writing last November in Arms Control Today, Cirincione said that Bush non-proliferation officials are leaving "office like financiers fleeing busted Wall Street banks, with
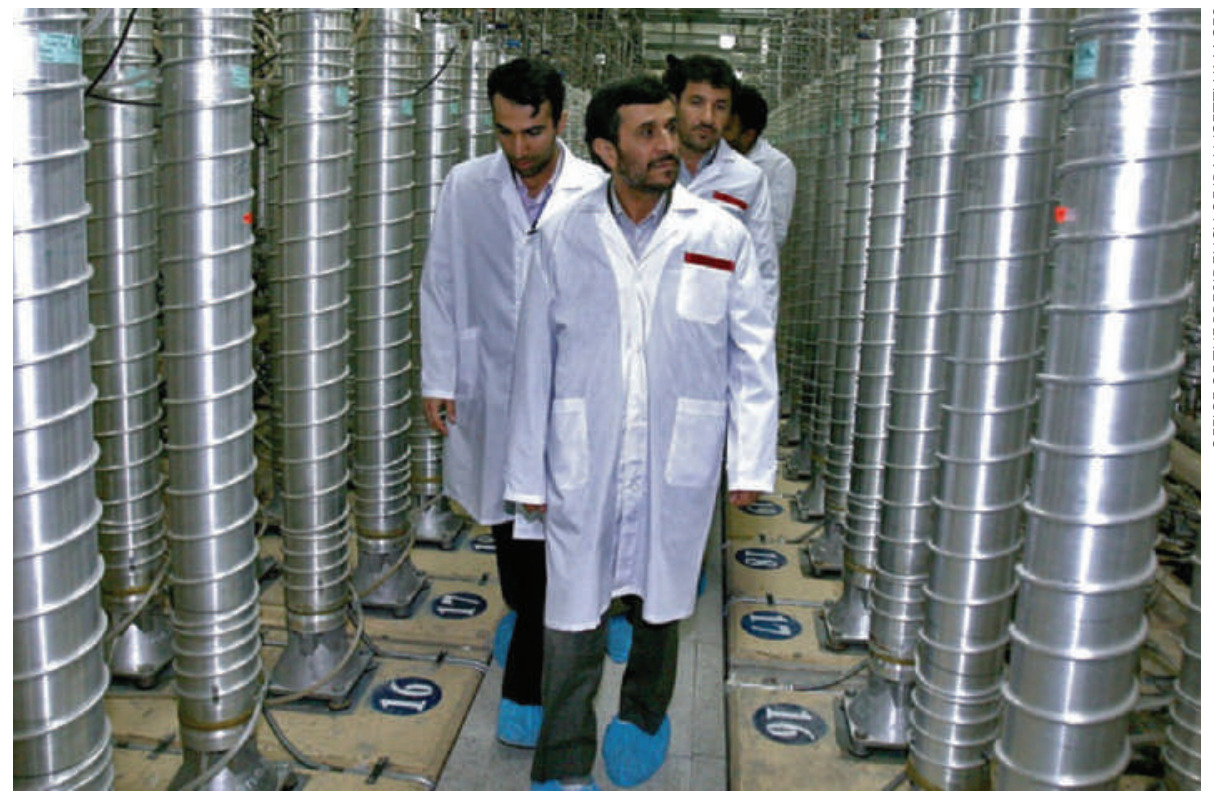

President Mahmoud Ahmadinejad of Iran (centre) has overseen an expansion of the country's uranium-enrichment facility.

precious assets squandered on risky ventures, once-solid institutions crumbling, surpluses turned into gaping deficits, and a string of problems mismanaged into crises that threaten to bring down a decades-old global regime".

"The Bush administration effectively walked away from proven arms-control and disarmament agreements," says Kimball — most obviously the NPT. Kimball and other armscontrol experts are the first to admit that the NPT regime and its related legislation are far from perfect. But they argue that the treaty has succeeded in creating a diplomatic space and norms that have largely prevented the appearance of new nuclear-weapons states. Although India, Pakistan, Israel and North Korea have developed nuclear weapons since the treaty came into effect in 1970, these experts say, many more nations have renounced their programmes to develop nuclear weapons. Without this nonproliferation system, the world might contain 30-40 nuclear-weapons states, they say. And should the system founder, they add, many new nuclear-weapons states would probably emerge, and this in turn would increase the risk of terrorists getting their hands on a bomb.

Despite that risk, says Rebecca Johnson, founding director of the London-based Acronym Institute for Disarmament Diplomacy, the Bush White House viewed multilateral arms-control agreements as constraining US action yet offering the nation few benefits. So after the terrorist attacks of 11 September 2001, the administration effectively repudiated the 'grand bargain' that is the core of the NPT.

\section{Give and take}

That bargain calls for the United States, Russia, the United Kingdom, France and China - the five states that had developed nuclear weapons before the NPT came into effect - to work to eliminate their stocks. In addition, these states undertook, albeit unofficially, to use their weapons only as a last resort in the event of a nuclear attack. In return, other states agreed not to develop nuclear weapons, and were guaranteed an 'inalienable right' to use nuclear energy for peaceful purposes.

In 2002, however, reviews of US defence and nuclear policy enshrined a new 'Bush doctrine.' On the plus side, the doctrine formalized the post-cold-war reality: nuclear weapons were no longer central to foreign policy with Russia and China, who had ceased to be the nation's 
mortal enemies. And it accurately reflected the new, twenty-first-century reality: the immediate threat was no longer full-scale nuclear war, but that terrorists might obtain and use a nuclear bomb. The problem was how the doctrine responded to this new reality. It has been a "disaster", says Paine. It has "completely backfired" in terms of non-proliferation.

For example, the doctrine authorized preemptive war against states considered to be developing weapons of mass destruction. It also left open for the first time the possibility of using nuclear weapons against states that did not have them, and blurred the historic red line between nuclear and conventional weapons by allowing tactical nuclear weapons to be used to attack enemy targets such as hardened bunkers. In doing so, the doctrine directly encouraged proliferation by countries in the US sights, says Bates Gill, director of the Stockholm International Peace Research Institute. He argues that it helped to convince countries such as Iran and North Korea that they needed to have nuclear weapons as deterrents to stave off potential US attacks. But if these two countries acquire nuclear arsenals it could trigger new nucleararms races in Asia and the Middle East, and perhaps beyond.

Bush initially refused to negotiate with either country, which "exacerbated" the problem, says Kimball. At least partly as a result of that missed opportunity, North Korea exploded a nuclear test device in 2006, and Iran now stands just months away from having enriched enough uranium for a bomb. Only recently has the United States started talks with North Korea, and it has now made tentative moves to negotiate with Iran.

On a broader level, say non-proliferation experts, the Bush doctrine's undermining of the NPT had a chilling effect on global nonproliferation efforts. It contributed directly to the collapse of the 2005 review conference of the NPT, in which member states failed to make any progress on a series of 13 measures that they had agreed to at the previous review conference five years earlier. These measures included the Comprehensive Nuclear-Test-Ban Treaty and a Fissile Material Cut-Off Treaty to outlaw the production of new weapons material.

Bush delivered another blow to the NPT when he signed a deal with India to force the lifting of an international ban on nuclear trade with the country, says Gill. The deal set a dangerous precedent by rewarding a country that has refused to sign the NPT and that has developed nuclear weapons, he adds. It also alienated countries that had abandoned their nuclear-weapons programmes to join the NPT. "In a word it has been negative," Gill says.

Dismantling the multilateral non-proliferation

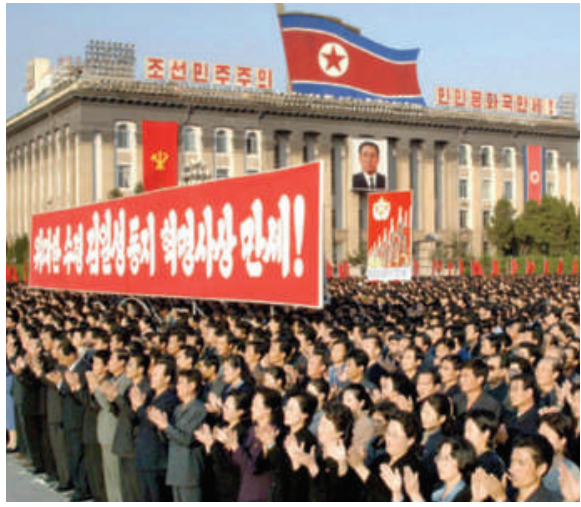

North Korea's 2006 nuclear test was a cause of celebration for the regime.

system further, in 2002, the United States withdrew from the Anti-Ballistic Missile Treaty negotiated with the Soviet Union in 1972, so that it could pursue its plans to build missile-defence shields against nuclear warheads. "This set a very dangerous precedent of a major country withdrawing from a major arms-control agreement," says Pavel Podvig, an expert on Russian nuclear affairs at the Center for International Security and Cooperation at Stanford University in California.

The Bush administration has also "basically dropped the ball" on nuclear-arms reductions with Russia, says Podvig. Large reductions in arsenals were nego-

"We have an opportunity
to shift directions, and
to repair our nuclear
non-proliferation and
disarmament strategies."
- Daryl Kimball

stockpile stewardship programme launched in 1994 to maintain the US arsenal through simulation and physics rather than nuclear testing. The programme has defied sceptics, says von Hippel, and has been largely successful in demonstrating that existing US nuclear warheads are reliable enough not to need imminent replacement.

But perhaps the most significant development in non-proliferation has emerged in the United States not because of the Bush administration, but despite it. This is the bipartisan groundswell for a major new commitment to disarmament, says Johnson. Consensus is growing that nuclear weapons are more of a liability than an asset now that the major threat to the country is a terrorist nuclear attack. The continued existence of massive nuclear arsenals, and the huge and inadequately secured stockpiles of weapons-grade fissile material around the world make this threat even more severe.

The result is a movement to develop a comprehensive roadmap catalysed by Sam Nunn, former chairman of the Senate Committee on Armed Services and co-chair of the tiated as part of the Strategic Arms Reduction Treaty initiated by Ronald Reagan in 1982. But the treaty expires at the end of this year, and no follow-up has been pursued. "The Bush administration consciously made the decision that it was not going to seek any new agreement," says Podvig. And the beneficial scientific and political dialogue that the agreements opened between the signatories has atrophied, he says.

\section{Positive progress}

There are some bright spots in the Bush legacy. Behind-the-scenes US and British diplomacy helped to persuade Libya to give up its programme of weapons of mass destruction in 2003. That same year, the United States helped to dismantle the vast black-market network of uranium enrichment and nuclear-weapons technologies run by Abdul Qadeer Khan, former head of Pakistan's nuclear programme. And initiatives to secure stocks of nuclearweapons material worldwide have also progressed somewhat, says von Hippel.

Another positive development - albeit one started during the previous administration of Bill Clinton - is the maturing of the
Nuclear Threat Initiative, a non-profit organization that aims to reduce the threat of nuclear and other weapons of mass destruction; George Schultz and Henry Kissinger, former secretaries of state; and William Perry, a former secretary of defence. The project aims to disarm the nuclear-weapons states, and in so doing gain multilateral support for a tougher international regime to counter nuclear terrorism and nuclear proliferation. Adding momentum, the Global Zero campaign put in place to back the plan was launched in Paris last month by prominent world figures, including former US president Jimmy Carter and other former heads of state.

The next NPT review conference, in 2010, will test whether such efforts are paying off. Experts have high expectations for the meeting, as US president-elect Barack Obama made the reinforcement of multilateral non-proliferation and disarmament efforts a central part of his election campaign (see page 235). "We have an opportunity here in the United States to shift directions, and to repair our nuclear non-proliferation and disarmament strategies," says Kimball. "You can never make up completely for lost time," says von Hippel, "but there certainly is a feeling that we now have to do the best we can to make up for the lost time of the Bush administration." Declan Butler is a senior reporter at Nature, based in France.

See Editorial, page 235. 